Egyptian Journal of Aquatic Biology \& Fisheries

Zoology Department, Faculty of Science,

Ain Shams University, Cairo, Egypt.

ISSN $1110-6131$

Vol. 24 (7): 943- 954 (2020)

www.ejabf.journals.ekb.eg

\title{
Nutrient Composition of Small Indigenous Fish Species (SIS) from Homestead Ponds of Noakhali Coast, Bangladesh
}

\section{Rafikul Islam ${ }^{1}$, Mohammad Belal Hossain ${ }^{1 *}$, Md. Nahidul Islam ${ }^{1}$, Md. Monirul Islam², Md. Tazul Islam ${ }^{3}$}

${ }^{1}$ Fisheries \& Marine Science, Noakhali Science \& Technology University, Noakhali, Bangladesh

${ }^{2}$ Nutrition Unit, Bangladesh Agricultural Research Council, Farmgate, Dhaka-1215

${ }^{3}$ Globe Agrovet Limited, Mirwarishpur, Begumgonj, Noakhali-3823

"Corresponding Author: mbhnstu@gmail.com

\section{ARTICLE INFO \\ Article History: \\ Received: Oct. 18, 2020 \\ Accepted: Dec. 04, 2020 \\ Online: Dec. 30, 2020}

\section{Keywords:}

Proximate composition;

Small Indigenous

Species (SIS);

Noakhali coast;

Homestead pond.

\section{ABSTRACT}

Estimating the nutrient composition of edible fish is the most important aspect of fish nutrition. Ten small indigenous species (SIS) were collected from the homestead ponds of the Noakhali coast, Bangladesh, to estimate and compare their nutrient composition. The major nutrient compositions (like protein, fat, moisture, ash, and carbohydrate) of raw fish were estimated using the Association of Official Analytical Chemists methods. The protein content (\%) of Colisa fasciatus, Amblypharyngodon mola, Puntius ticto, Puntius sarana, Macrognathus aculeatus, Mystus tengara, Anabas testudineus, Heteropneustes fossilis, Channa punctatus, and Clarias batrachus were found to be $14.51 \pm 1.2$, $14.57 \pm 1.19, \quad 14.39 \pm 1.23,16.31 \pm 0.48,17.3 \pm 1.74,13.73 \pm 1.34,13.95 \pm 0.43$, $14.11 \pm 0.82,13.18 \pm 0.57$, and $17.15 \pm 1.27$, respectively. The lipid content $(\%)$ of C. fasciatus, A. mola, P. ticto, P. sarana, M. aculeatus, M. tengara, A. testudineus, $H$. fossilis, $C$. punctatus, and $C$. batrachus were found to be $1.55 \pm 0.11,2.51 \pm 0.26,2.14 \pm 0.18,3.05 \pm 0.09,1.67 \pm 0.17,2.54 \pm 0.18,2.85 \pm 0.08$, $2.51 \pm 0.21,2.11 \pm 0.09$, and 3.1 \pm 0.23 , respectively. The ash content $(\%)$ of $C$. fasciatus, A. mola, P. ticto, P. sarana, M. aculeatus, M. tengara, A. testudineus, $H$. fossilis, C. punctatus, and $C$. batrachus were found to be $3.43 \pm 0.23$, $3.1 \pm 0.32,3.72 \pm 0.32,2.79 \pm 0.08,2.44 \pm 0.24,2.56 \pm 0.17,3.06 \pm 0.08,1.68 \pm 0.1$, $1.7 \pm 0.07$, and $2.15 \pm 0.15$, respectively. Moisture content varied from $75.27 \%$ in $P$. sarana to $81.05 \%$ in $C$. punctatus. The carbohydrate content ranged from $1.81 \%$ ( $H$. fossilis) to $3.28 \%$ ( $M$. aculeatus). One way analysis revealed significant variation $(\mathrm{P}<0.05)$ in the mean value of nutrient contents among the fish species. From the present study, it could be concluded that the homestead ponds contain fish with a good source of nutrition that can help in decreasing the nutrient deficiency in Bangladesh. Thus, it can be added to the cultural system for consumption, as well as, supporting the livelihood of the coastal people.

\section{INTRODUCTION}

Bangladesh is gratified with immense open water resources with a wide range of aquatic diversity. Its biodiversity includes almost 260 freshwater fish species (Hasan et 
al., 2013; DoF, 2018). Small indigenous species (SIS) is an important freshwater group of fish in Bangladesh. SIS grows to a size of about $25-30 \mathrm{~cm}$ in the mature or adult stage (Mohanty et al., 2011). SIS such as Khalisha (Colisa fasciatus), Mola (Amblypharyngodon mola), Punti (Puntius ticto), Sharpunti (Puntius sarana), Tarabaim (Macrognathus aculeatus), Tengra (Mystus tengara), Koi (Anabas testudineus), Shing (Heteropneustes fossilis), Taki (Channa punctatus), and Magur (Clarias batrachus) are considered as a delicious and nutritive food in Bangladesh. Besides being an important source of proteins, these small indigenous fish species are enriched with micronutrients, minerals, and vitamins.

The proximate composition comprises the estimation of moisture, protein, fat, and ash component in the fresh fish body. The percentage of composition of these constituents accounts for about 96-98\% of the total tissue constituents in the fish (Nowsad, 2007). In Indian coastal waters, the values of these constituents in the common fish species followed the pattern moisture $(65-90 \%)>$ protein $(10-22 \%)>$ lipid (1-20\%) > ash (0.5-5\%). Carbohydrates, vitamins, minerals, and other non-protein nitrogenous compounds were also present in small quantities (Stansby, 1962).

Noakhali is one of the Southern coastal districts of Bangladesh. Homestead ponds in Noakhali are important habitats of small indigenous fish species in which it grows without care and culture. These fishes enter the ponds from floodwater from different sources, grow and reproduce there. But in most cases, these small ponds are covered with shade, received leaves of trees and organic matters from homestead areas having aquatic weeds, bushes, holes, and roots of trees. In these ponds, Colisa fasciatus, Amblypharyngodon mola, Puntius ticto, Puntius sarana, Macrognathus aculeatus, Mystus tengara, Anabas testudineus, Heteropneustes fossilis, Channa punctatus, and Clarias batrachus provide major catches from homestead ponds. In the past, some of these small fish species were thought to be weed fishes and were removed using pesticides. However, recently, these species have been viewed as an important source of essential macro-and micro-nutrients, which can play a vital role in the reduction of malnutrition in Bangladesh (Ahmed et al., 1997; Thilsted et al., 1997; Hossain, 1997; Hossain \& Ahsan, 2003; and Wahab et al., 2003).

Mazumder et al. (2008) examined the proximate composition of some (SIS) in Bangladesh. Begum \& Minar (2012) carried out a comparative study on the body composition of different SIS, shellfish, and ilish in Bangladesh. However, the proximate composition of SIS of homestead ponds fish has been less investigated. Therefore, considering the importance of the small indigenous species in human nutrition, the present study was undertaken to analyze the proximate composition of small indigenous fish species harvested from homestead ponds of Noakhali coast, Bangladesh. 


\section{MATERIALS AND METHODS}

\section{Sample collection}

Ten fresh small indigenous fish species (viz. Khalisha (Colisa fasciatus), Mola (Amblypharyngodon mola), Punti (Puntius ticto), Sarpunti (Puntius sarana), Tarabaim (Macrognathus aculeatus), Tengra (Mystus tengara), Koi (Anabas testudineus), Shing (Heteropneustes fossilis), Taki (Channa punctatus), and Magur (Clarias batrachus)) were collected during the period from April to June 2019 from the homestead ponds and the drained pond of Noakhali coast (Figure 1). Samples were collected using cast and push nets and stored in an icebox before laboratory analysis. The number of samples collected for each SIS was dependent on the average size of each fish species and a total weight of approximately one kilogram for each sample.

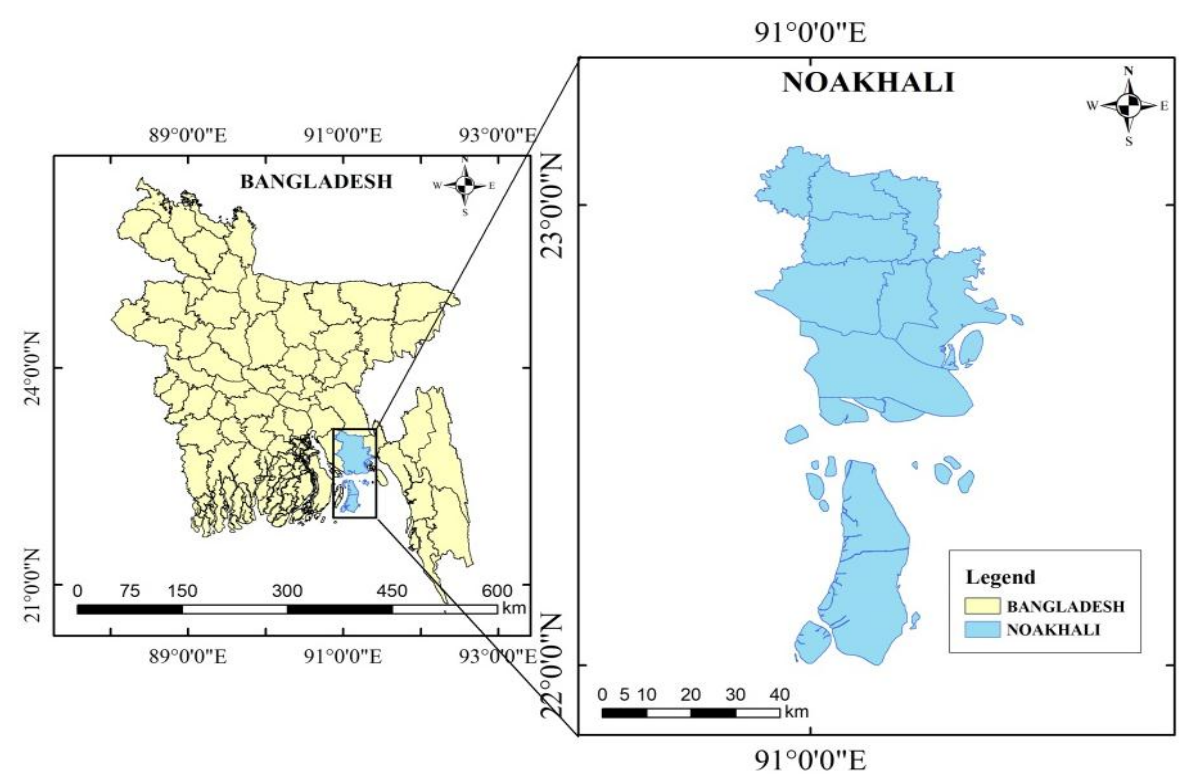

Fig. (1): Sample collected from homestead ponds (Subornochar) of the Noakhali coast

\section{ample preparation}

Captured fish samples were then transported to the laboratory of Glove Agrovet Ltd, Mirwarishpur, Noakhali. Samples were carefully washed with cooled tap water. Fins, gills, and viscera were removed and again washed with tap water to remove blood, slime, and unnecessary flesh. After washing, the fish samples were cut into small pieces and finally ground with a blender to produce a homogenous mixture. 


\section{Proximate composition}

For analysis, the proximate compositions of each species were analyzed using conventional methods of the Association of Official Analytical Chemists (AOAC, 1995). Each sample was run in three replicates.

Moisture: The moisture content was determined by drying the sample at $105{ }^{\circ} \mathrm{C}$ to a constant weight for 24 hours.

$$
\text { Moisture content }(\%)=\frac{\text { Weight loss }}{\text { original weight of the sample taken }} * 100
$$

Ash: Total ash content was evaluated from weighed samples in a porcelain crucible placed in a muffle furnace at $600{ }^{\circ} \mathrm{C}$ for 6 hours.

$$
\text { Ash content }(\%)=\frac{\text { Weight of dry sample }}{\text { original weight of the sample taken }} * 100
$$

Crude Protein: The protein content of the fish was determined by micro-kjeldahl method. Samples $(0.5 \mathrm{~g})$ were digested in the digestion unit for 45 minutes. The digested samples were then distilled in a distillation unit and titrated with $0.1 \mathrm{~N}$ $\mathrm{HCl}$. Crude protein was obtained by multiplying the total nitrogen by a conversion factor of 6.25 .

$$
\begin{gathered}
\text { Protein content }(\%)=\% \text { of total } \mathbf{N}_{2} * \mathbf{6 . 2 5} \\
\mathbf{N}_{2}(\%)=(\text { Titration reading-blank reading }) *(\text { Strength of Acid }) *(100 / 5) * \\
(100 / \text { weight of the sample })
\end{gathered}
$$

Crude Lipid: The estimation of the fat content in the experimental raw fish was accomplished by the Bligh and Dyer method (Bligh and Dyer, 1959):

$$
\text { Fat content }(\%)=\frac{\text { Weight of the residue }}{\text { Weight of the sample taken }} * 100
$$

Total carbohydrate: Carbohydrate content was determined by calculating the difference between $100 \%$ and the sum of values of moisture, protein, fiber, lipid, and ash.

\section{Data analysis}

MS Excel 2010 was used for data analysis. The study performed Analysis of Variance (ANOVA) to test the significant variation $(\mathrm{p}<0.05)$ in nutrient contents among the investigated fish species. 


\section{RESULTS AND DISCUSSION}

\section{Protein content (\%):}

The protein content ranged from $13.18 \%$ to $17.3 \%$ among the examined species (Table 1). The lowest protein content recorded was in C. punctatus $(13.18 \%)$, whereas the highest was in M. aculeatus (17.3\%). The protein content (\%) of C. fasciatus, A. mola, P. ticto, P. sarana, M. aculeatus, M. tengara, A. testudineus, H. fossilis, C. punctatus, and C. batrachus were found to be $14.51 \pm 1.2,14.57 \pm 1.19,14.39 \pm 1.23$, $16.31 \pm 0.48, \quad 17.3 \pm 1.74, \quad 13.73 \pm 1.34, \quad 13.95 \pm 0.43, \quad 14.11 \pm 0.82, \quad 13.18 \pm 0.57$, and 17.15 \pm 1.27 , respectively (Figure 2).

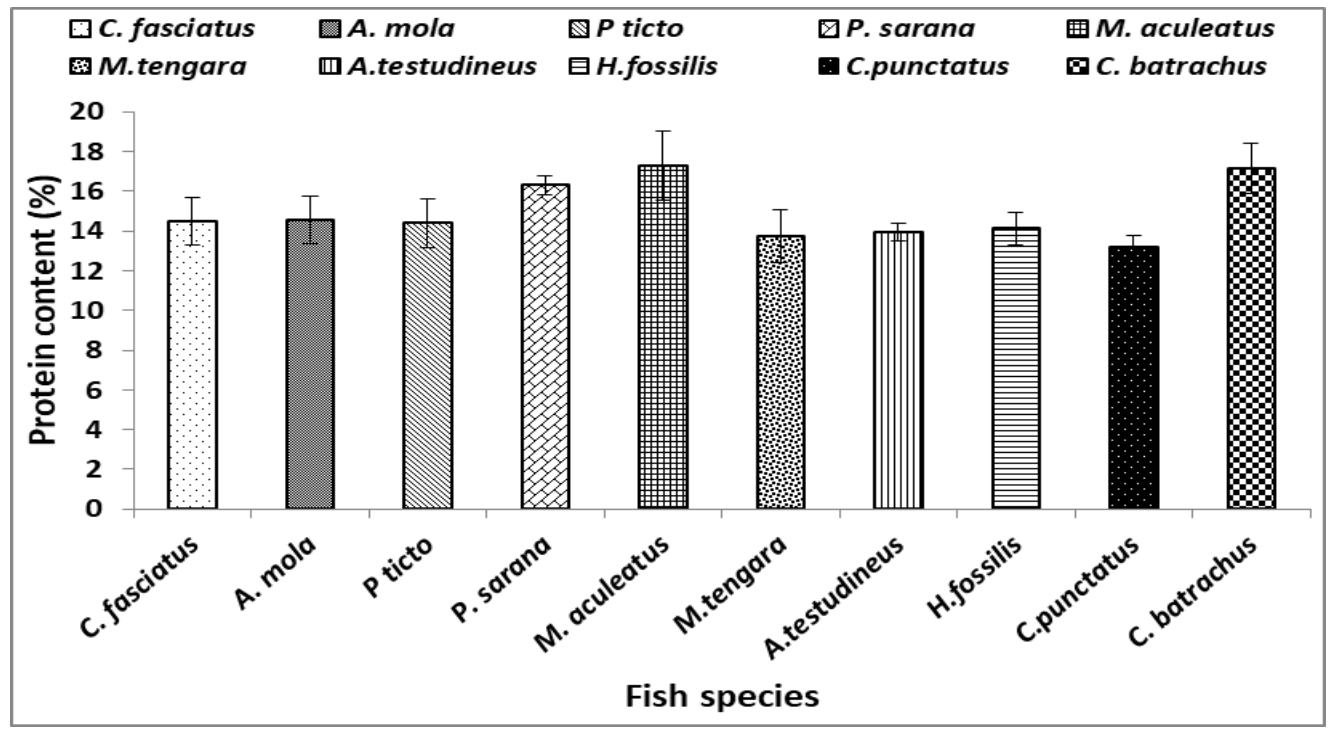

Fig. (2): Variation of protein contents (\%) among the fish species

Protein contents of C. fasciatus, A. mola, P. ticto, P. sarana, M. aculeatus, M. tengara, A. testudineus, H. fossilis, C. punctatus, and C.batrachus were similar to the findings of other researchers (Hossain et al., 1999; Mazumder et al., 2008; Siddique et al., 2011; Ahmed et al., 2012; Begum \& Minar, 2012; Paul et al., 2017; Jena et al., 2018; and Kamruzzaman et al., 2018). Protein content in A. testudineus (19.50\%) recorded by Ahmed et al. (2012) was higher than that of the present study (Table 1). This deviation may occur due to size, seasonal variation or feeding habits of the fish. The results also state that protein contents show an inverse relationship with moisture contents. 
Table 1. Values of proximate composition of the examined fish species collected from homestead ponds in the present study in comparison with previous studies from other localities

\begin{tabular}{|c|c|c|c|c|c|c|}
\hline Species & Moisture & Protein & Lipid & Ash & Carbohydrate & Reference \\
\hline Colisa fasciatus & $\begin{array}{l}\mathbf{7 8 . 3 2} \pm 1.45 \\
0.75 \\
73.18 \pm 0.17 \\
74.44\end{array}$ & $\begin{array}{l}\mathbf{1 4 . 5 1} \pm \mathbf{1 . 2} \\
15.82 \\
13.86 \pm 0.09 \\
14.14\end{array}$ & $\begin{array}{l}\mathbf{1 . 5 5} \pm \mathbf{0 . 1 1} \\
2.58 \\
4.79 \pm 0.18 \\
7.25\end{array}$ & $\begin{array}{l}\mathbf{3 . 4 3} \pm \mathbf{0 . 2 3} \\
0.85 \\
3.14 \pm 0.04 \\
3.97\end{array}$ & $\begin{array}{l}\mathbf{2 . 1 9} \pm 0.3 \\
- \\
5.03 \pm 0.41 \\
-\end{array}$ & $\begin{array}{l}\text { Present study } \\
{[1]} \\
{[2]} \\
{[3]}\end{array}$ \\
\hline Amblypharyngodon mola & $\begin{array}{l}\mathbf{7 7 . 9 9} \pm \mathbf{1 . 3 8} \\
76.68 \\
74.68 \pm 0.09 \\
76.38 \pm 2.52 \\
76.59\end{array}$ & $\begin{array}{l}\mathbf{1 4 . 5 7 \pm 1 . 1 9} \\
17.95 \\
16.75 \pm 0.12 \\
18.46 \pm 1.86 \\
14.75\end{array}$ & $\begin{array}{l}\mathbf{2 . 5 1} \pm \mathbf{0 . 2 6} \\
2.87 \\
1.84 \pm 0.03 \\
4.10 \pm 0.98 \\
5.15\end{array}$ & $\begin{array}{l}\mathbf{3 . 1} \pm \mathbf{0 . 3 2} \\
2.50 \\
1.93 \pm 0.09 \\
1.64 \pm 0.54 \\
3.28\end{array}$ & $\begin{array}{l}\mathbf{1 . 8 3} \pm \mathbf{0 . 3 6} \\
- \\
4.79 \pm 0.17 \\
- \\
-\end{array}$ & $\begin{array}{l}\text { Present study } \\
{[1]} \\
{[2]} \\
{[4]} \\
{[3]}\end{array}$ \\
\hline Puntius ticto & $\begin{array}{l}\mathbf{7 7 . 3} \pm \mathbf{1 . 9 5} \\
75.02 \\
71.00\end{array}$ & $\begin{array}{l}\mathbf{1 4 . 3 9 \pm 1 . 4 7} \\
18.08 \\
16.43\end{array}$ & $\begin{array}{l}\mathbf{2 . 1 4 \pm . 0 2 6} \\
3.56 \\
7.12\end{array}$ & $\begin{array}{l}3.72 \pm .032 \\
3.34 \\
5.22\end{array}$ & $\begin{array}{l}2.46 \pm .022 \\
- \\
-\end{array}$ & $\begin{array}{l}\text { Present study } \\
{[1]} \\
{[3]}\end{array}$ \\
\hline Puntius sarana & $\begin{array}{l}\mathbf{7 5 . 2 7} \pm \mathbf{0 . 7 2} \\
77.31 \\
71.39 \pm 0.54\end{array}$ & $\begin{array}{l}\mathbf{1 6 . 3 1 \pm 0 . 4 8} \\
18.30 \\
16.73 \pm 0.92\end{array}$ & $\begin{array}{l}\mathbf{3 . 0 5} \pm \mathbf{0 . 0 9} \\
3.69 \\
9.00 \pm 1.09\end{array}$ & $\begin{array}{l}2.79 \pm 0.08 \\
- \\
2.02 \pm 0.25\end{array}$ & $\begin{array}{l}2.58 \pm 0.07 \\
- \\
-\end{array}$ & $\begin{array}{l}\text { Present study } \\
{[5]} \\
{[6]}\end{array}$ \\
\hline Macrognathus aculeatus & $\begin{array}{l}75.31 \pm 2.48 \\
75.12 \pm 0.40 \\
78.12\end{array}$ & $\begin{array}{l}\mathbf{1 7 . 3 \pm 1 . 7 4} \\
16.53 \pm 0.06 \\
15.32\end{array}$ & $\begin{array}{l}\mathbf{1 . 6 7} \pm \mathbf{0 . 1 7} \\
3.02 \pm 0.13 \\
4.12\end{array}$ & $\begin{array}{l}2.44 \pm 0.24 \\
3.58 \pm 0.05 \\
2.25\end{array}$ & $\begin{array}{l}3.28 \pm 0.34 \\
1.75 \pm 0.33 \\
-\end{array}$ & $\begin{array}{l}\text { Present study } \\
{[2]} \\
{[3]}\end{array}$ \\
\hline Mystus tengara & $\begin{array}{l}\mathbf{7 9 . 1 2} \pm 2.05 \\
77.17 \\
74.26 \pm 0.29 \\
79.45\end{array}$ & $\begin{array}{l}\mathbf{1 3 . 7 3} \pm \mathbf{1 . 3 4} \\
17.86 \\
13.33 \pm 0.29 \\
13.07\end{array}$ & $\begin{array}{l}\mathbf{2 . 5 4} \pm \mathbf{0 . 1 8} \\
3.48 \\
3.84 \pm 0.29 \\
2.76\end{array}$ & $\begin{array}{l}\mathbf{2 . 5 6 \pm 0 . 1 7} \\
1.48 \\
4.11 \pm 0.15 \\
4.30\end{array}$ & $\begin{array}{l}\mathbf{2 . 0 6} \pm \mathbf{0 . 5 2} \\
- \\
4.46 \pm 0.39 \\
-\end{array}$ & $\begin{array}{l}\text { Present study } \\
{[1]} \\
{[2]} \\
{[3]}\end{array}$ \\
\hline Anabas testudineus & $\begin{array}{l}77.6 \pm 0.63 \\
76.60 \\
68.00 \pm 1.77\end{array}$ & $\begin{array}{l}\mathbf{1 3 . 9 5} \pm \mathbf{0 . 4 3} \\
19.50 \\
16.91 \pm 0.59\end{array}$ & $\begin{array}{l}\mathbf{2 . 8 5} \pm \mathbf{0 . 0 8} \\
2.27 \\
6.98 \pm 1.49\end{array}$ & $\begin{array}{l}3.06 \pm 0.08 \\
1.62 \\
5.50 \pm 0.49\end{array}$ & $\begin{array}{l}2.54 \pm 0.05 \\
- \\
-\end{array}$ & $\begin{array}{l}\text { Present study } \\
{[1]} \\
{[7]}\end{array}$ \\
\hline Heteropneustes fossilis & $\begin{array}{l}\mathbf{7 9 . 8 9} \pm \mathbf{1 . 1 8} \\
80.44 \\
78.21 \pm 0.67 \\
78.94 \pm 1.08\end{array}$ & $\begin{array}{l}\mathbf{1 4 . 1 1} \pm \mathbf{0 . 8 2} \\
15.14 \\
15.28 \pm 0.28 \\
14.09 \pm 0.96\end{array}$ & $\begin{array}{l}\mathbf{2 . 5 1} \pm \mathbf{0 . 2 1} \\
3.49 \\
1.96 \pm 0.50 \\
6.47 \pm 0.56\end{array}$ & $\begin{array}{l}\mathbf{1 . 6 8} \pm \mathbf{0 . 1} \\
0.94 \\
2.48 \pm 0.09 \\
0.95 \pm 0.07\end{array}$ & $\begin{array}{l}\mathbf{1 . 8 1 \pm 0 . 0 4} \\
- \\
- \\
-\end{array}$ & $\begin{array}{l}\text { Present study } \\
{[1]} \\
{[8]} \\
{[9]}\end{array}$ \\
\hline Channa punctatus & $\begin{array}{l}\mathbf{8 1 . 0 5} \pm \mathbf{0 . 8 2} \\
81.93 \\
75.43 \\
78.99 \pm 2.21\end{array}$ & $\begin{array}{l}\mathbf{1 3 . 1 8} \pm \mathbf{0 . 5 7} \\
15.22 \\
17.15 \\
15.23 \pm 1.89\end{array}$ & $\begin{array}{l}\mathbf{2 . 1 1} \pm \mathbf{0 . 0 9} \\
1.60 \\
1.87 \\
2.21 \pm 0.16\end{array}$ & $\begin{array}{l}\mathbf{1 . 7 \pm 0 . 0 7} \\
1.25 \\
5.49 \\
2.89 \pm 0.27\end{array}$ & $\begin{array}{l}1.96 \pm 0.09 \\
- \\
- \\
-\end{array}$ & $\begin{array}{l}\text { Present study } \\
{[1]} \\
{[3]} \\
{[10]}\end{array}$ \\
\hline Clarias batrachus & $\begin{array}{l}\mathbf{7 5 . 2 8} \pm \mathbf{1 . 8 3} \\
80.74 \\
78.69 \pm 0.77\end{array}$ & $\begin{array}{l}\mathbf{1 7 . 1 5} \pm \mathbf{1 . 2 7} \\
15.22 \\
15.33 \pm 0.20\end{array}$ & $\begin{array}{l}3.1 \pm 0.23 \\
3.08 \\
2.03 \pm 0.28\end{array}$ & $\begin{array}{l}\mathbf{2 . 1 5} \pm \mathbf{0 . 1 5} \\
0.95 \\
2.38 \pm 0.07\end{array}$ & $\begin{array}{l}2.33 \pm 0.18 \\
- \\
-\end{array}$ & $\begin{array}{l}\text { Present study } \\
{[1]} \\
{[8]}\end{array}$ \\
\hline
\end{tabular}




\section{Lipid content (\%):}

The lipid content (\%) varied from 1.55 to 3.1 (Table 1). The lowest lipid content (1.55\%) was found in C. fasciatus, whereas the highest (3.1\%) was in C. batrachus. The lipid content (\%) of C. fasciatus, A. mola, P. ticto, P. sarana, M. aculeatus, M. tengara, A. testudineus, H. fossilis, C. punctatus, and C. batrachus were found to be $1.55 \pm 0.11, \quad 2.51 \pm 0.26, \quad 2.14 \pm 0.18, \quad 3.05 \pm 0.09, \quad 1.67 \pm 0.17, \quad 2.54 \pm 0.18, \quad 2.85 \pm 0.08$, $2.51 \pm 0.21,2.11 \pm 0.09$, and $3.1 \pm 0.23$, respectively (Figure 3).

Results of lipid content in C. fasciatus, A. mola, P. ticto, P. sarana, M. aculeatus, $M$. tengara, A. testudineus, $H$. fossilis, $C$. punctatus, and C. batrachus were in line with the findings of other studies (Hossain et al., 1999; Mazumder et al., 2008; Siddique et al., 2011; Ahmed et al., 2012; Paul et al., 2015; Jena et al., 2018; and Kamruzzaman et al., 2018) (Table 1). The highest amount of lipid was recorded by Hossain $\boldsymbol{e t}$ al. (1999) in C. fasciatus and P. ticto, Begum \& Minar (2012) in P. sarana, and Paul et al. (2017) in A. testudineus. This finding might be attributed to the difference in size, sex, organ, fasting condition of the fish, or fat oxidation.

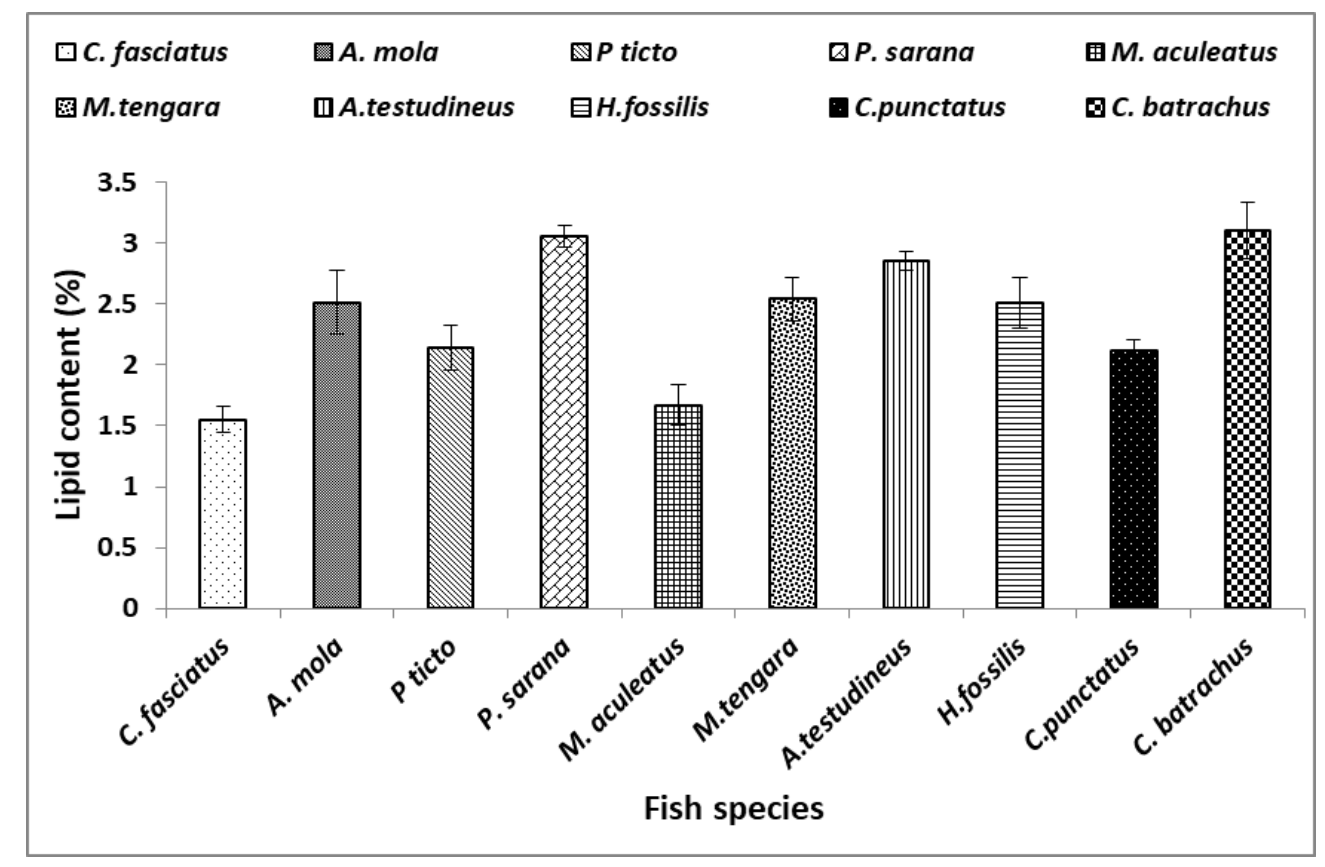

Fig. (3): Variation of lipid contents (\%) among the fish species

\section{Ash content (\%):}

Ash content (\%) varied among the examined species (Table 1). The lowest ash content $(1.68 \%)$ was recorded in $H$. fossilis, whereas the highest ash content $(3.72 \%)$ was in P. ticto. The ash content (\%) of C. fasciatus, A. mola, P. ticto, P. sarana, M. aculeatus, M. tengara, A. testudineus, $H$. fossilis, $C$. punctatus, and $C$. batrachus were 
found to be $3.43 \pm 0.23,3.1 \pm 0.32,3.72 \pm 0.32,2.79 \pm 0.08,2.44 \pm 0.24,2.56 \pm 0.17$, $3.06 \pm 0.08,1.68 \pm 0.1,1.7 \pm 0.07$, and $2.15 \pm 0.15$, respectively (Figure 4).

Table 1 showed that the ash contents of $C$. fasciatus, A. mola, P. ticto, P. sarana, M. aculeatus, M. tengara, A. testudineus, $H$. fossilis, C. punctatus, and C. batrachus were almost close to the results of other researchers (Hossain et al., 1999; Mazumder et al., 2008; Ahmed et al., 2012; Begum \& Minar, 2012; Paul et al., 2017; Jena et al., 2018; and Kamruzzaman et al., 2018). The ash content determined by Ahmed $\boldsymbol{e t}$ al. (2012) in C. fasciatus, Hossain et al. (1999) and Ahmed et al. (2012) in C. batrachus did not coincide with the present study. This deviation may be attributed to the variations in season and methods used in these studies. Results of the present study also indicated that the ash content of the small indigenous species was higher than other species due to the higher amount of skeleton in small indigenous species.

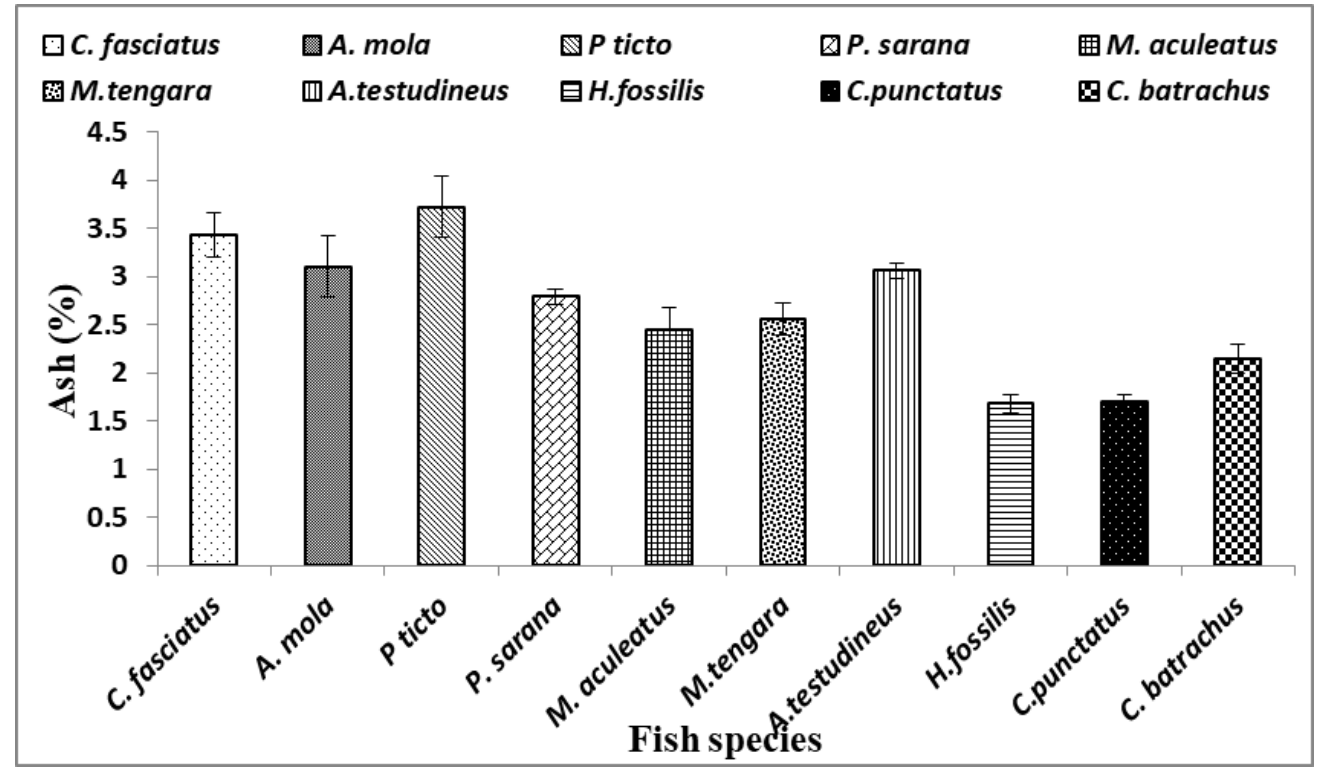

Fig. (4): Variation of ash contents (\%) among the fish species

\section{Moisture content (\%):}

The moisture content, in the present study, varied among the examined species (Table 1). The lowest moisture content $(75.27 \%)$ was recorded in P. sarana, whereas the highest $(81.05 \%)$ was in $C$. punctatus. The moisture content (\%) of $C$. fasciatus, $A$. mola, P. ticto, P. sarana, M. aculeatus, M. tengara, A. testudineus, H. fossilis, C. punctatus, and $C$. batrachus were found to be $78.32 \pm 1.45,77.99 \pm 1.38,77.3 \pm 1.95$, $75.27 \pm 0.72, \quad 75.31 \pm 2.48, \quad 79.12 \pm 2.05, \quad 77.61 \pm 0.63, \quad 79.89 \pm 1.18, \quad 81.05 \pm 0.82$, and $75.28 \pm 1.83$, respectively (Figure 5).

The results of the present study are similar to the findings of other researchers (Hossain et al., 1999; Mazumder et al., 2008; Siddique et al., 2011; Ahmed et al., 
2012; Begum \& Minar, 2012; Paul et al., 2015; Jena et al., 2018; and Kamruzzaman et al., 2018) (Table 1). However, Hossain et al. (1999) and Paul et al. (2017) recorded the lowest moisture values in P. Ticto and A. testudineus, respectively. This deviatation might be attributed to the difference in season or feeding habit of the species. The current results observed an inverse relationship between the amount of moisture and protein.

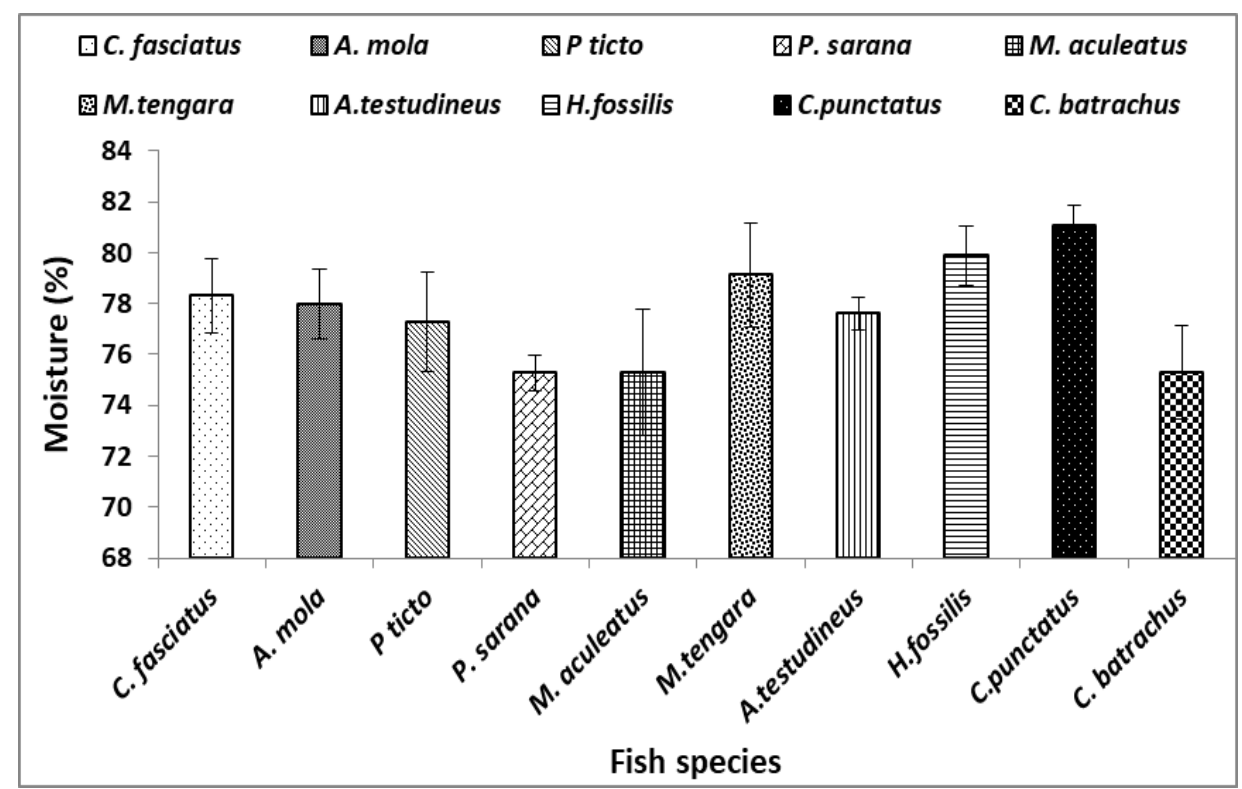

Fig. (5): Variation of moisture contents (\%) among the fish species

\section{Carbohydrate content $(\%)$ :}

The carbohydrate content, in the present study, ranged from $1.81 \%$ (H. fossilis) to 3.28\% (M. aculeatus) (Table 1). The carbohydrate content (\%) of C. fasciatus, A. mola, P. ticto, P. sarana, M.aculeatus, M. tengara, A. testudineus, H. fossilis, C. punctatus, and $C$. batrachus were found to be $2.19 \pm 0.3,1.83 \pm 0.36,2.46 \pm 0.22,2.58 \pm 0.07$, $3.28 \pm 0.34,2.06 \pm 0.52,2.54 \pm 0.05,1.81 \pm 0.04,1.96 \pm 0.09$, and $2.33 \pm 0.18$, respectively (Figure 6).

The present results coincided with the results of Jena $\boldsymbol{e t}$ al. (2018) in $M$. aculeatus and M. tengara (Table 1). Carbohydrate content is an important element of fish and it is supposed to be the first among the organic nutrients to be utilized to produce required energy (Heath, 1987). 


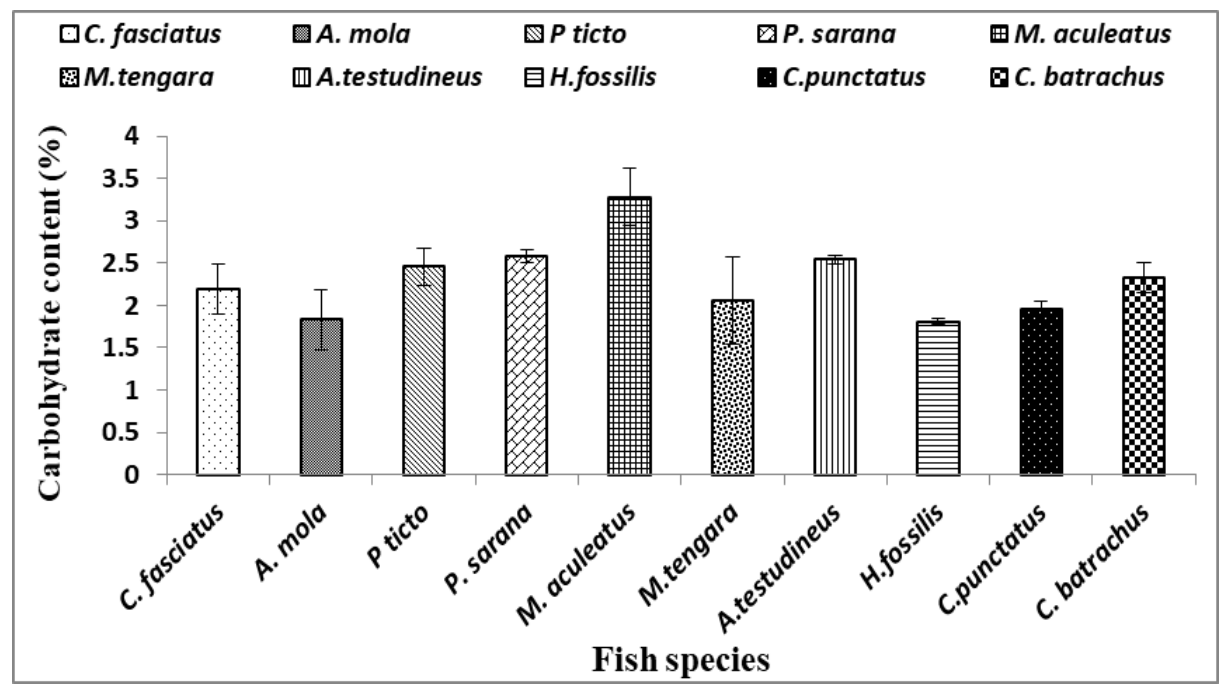

Fig. (6): Variation of carbohydrate contents (\%) among the fish species

The mean values of protein, lipid, ash, moisture and carbohydrate contents varied significantly $(\mathrm{P}<0.05)$ among the fish species (Table 2$)$.

Table 2. ANOVA table showing the variation in moisture, protein, lipid, ash, and carbohydrate contents among the investigated fish species

\begin{tabular}{lllllll}
\hline Nutrient & Source of Variation & SS & df & MS & F & p-value \\
\hline Moisture \% & Between groups & 108.399 & 9 & 12.0443 & 4.928 & $0.001447^{*}$ \\
& Within groups & 48.8811 & 20 & 2.44405 & & \\
Total & $\mathbf{1 5 7 . 2 8}$ & $\mathbf{2 9}$ & & & \\
& Between groups & 57.5326 & 9 & 6.39251 & 5.231 & $0.00101^{*}$ \\
& Within groups & 24.442 & 20 & 1.2221 & & \\
Lipid \% & Total & $\mathbf{8 1 . 9 7 4 6}$ & $\mathbf{2 9}$ & & & \\
& Between groups & 7.69328 & 9 & 0.854809 & 29.55 & $1.218 \mathrm{E}^{-09 *}$ \\
& Within groups & 0.578533 & 20 & 0.0289267 & & \\
Ash\% & Total & $\mathbf{8 . 2 7 1 8 2}$ & $\mathbf{2 9}$ & & & \\
& Between groups & 12.8997 & 9 & 1.4333 & 36.55 & $1.735 \mathrm{E}^{-10 *}$ \\
& Within groups & 0.784267 & 20 & 0.0392133 & & \\
& Total & $\mathbf{1 3 . 6 8 3 9}$ & $\mathbf{2 9}$ & & & \\
Carbohydrate & Between groups & 5.26547 & 9 & 0.585052 & 8.332 & $4.464 \mathrm{E}^{-05 *}$ \\
& Within groups & 1.4044 & 20 & 0.07022 & & \\
& Total & $\mathbf{6 . 6 6 9 8 7}$ & $\mathbf{2 9}$ & & & \\
\hline
\end{tabular}

SS: sum of square; df: degree of freedom MS: Mean square; F: F-statistic; $\%$ : percent.; * significant 


\section{CONCLUSION}

In a nutshell, results of the present study showed that the examined ten small indigenous fish species of homestead ponds contained a high amount of nutrients that can enhance the nutritional security in the rural area. Culturing these fish species will provide poor people with the required source of animal protein. The study recommends using homestead ponds in fish culture. Accordingly, future research works are needed to determine the minerals required to establish a nutritional database of SIS in homestead ponds.

\section{ACKNOWLEDGEMENT}

The research project was funded by PIU-BARC NATP-II (Project ID: 011). The authors are highly thankful to Glove Agrovet Limited, Mirwarishpur, Begumgonj, Noakhali, for providing facilities in their laboratory.

\section{REFERENCES}

Ahmed, K.; Hossain, M. A.; Huda, N. and Abdullah, M. (1997). Nutritional survey of rural Bangladesh; 1975-76. Institute of Nutrition and Food Science, University of Dhaka, 66pp.

Ahmed, S.; Rahman, A. F. M. A.; Mustafa, M. G.; Hossain, M. B. and Nahar, N. (2012). Nutrient composition of indigenous and exotic fishes of rainfed waterlogged paddy fields in Lakshmipur, Bangladesh. World Journal of Zoology, 7(2): 135-140.

AOAC (Association of Official Analytical Chemicals). (1995). Official Method of Analysis, $12^{\text {th }}$ edn., Association of official Analytical Chemists, Washington DC, 832pp.

Begum, M. and Minar, M. H. (2012). Comparative study about body composition of different sis, shell fish and ilish; commonly available in Bangladesh. Trends in Fisheries research, 1(1): $38-42$.

Bligh, E.G. and Dyer, W.J. (1959). A rapid method of total lipid extraction and purification. Journal of Biochemistry and Physiology, 37:911-917.

DoF (Department of Fisheries). (2018). Yearbook of Fisheries Statistics of Bangladesh, 201718; Fisheries Resources Survey System (FRSS), Department of Fisheries. Bangladesh: Ministry of Fisheries, 2018. Volume 35: 129.

Hassan, M. N., Rahman, M., Hossain, M. M., Nowsad, A. A. K. M., \& Hossain, M. B. (2013). Post-Harvest Loss and Shelf Life of Traditionally Smoked Shrimp Products Produced in Bangladesh. World Journal of Fish and Marine Science, 5(1): 14-19.

Heath, A.G. (1987). Water pollution and fish physiology. In Physiological Energetic. Ed. Boca Raton, CRC Press, USA, 131-163.

Hossain, M. A. (1997). Various aspects of small indigenous species (SIS) of fish in Bangladesh. Proc. Nat. Workshop on SIS Culture in Bangladesh. December 12, 1996, Key note speech, IFADEP September 2: 16-30. 
Hossain, M.A.; Afsana, K. and Azad Shah, A.K.M. (1999). Nutritional value of some small indigenous fish species (SIS) of Bangladesh. Bangladesh Journal of Fisheries Research, 3(1): $77-85$.

Hossain, M.A. and Ahsan, M. K. (2003). Small fish resources in the rivers, flood plains and upland areas of Bangladesh. Proceeding of BAU-ENRECA/DANIDA Workshop on Potentials of Small Indigenous Species of Fish (SIS) in Aquaculture \& Rice-Field stocking for Improved Food \& Nutrition Security in Bangladesh, 30-01 October, 2002, BAU, Mymensingh, Bangladesh, 87-96.

Jena, D.; Jena, A.K.; Panda, A.; Parhi, J.; Biswas, P. and Pattanaik, S.S. (2018). Proximate analysis of some small indigenous fish species (SIS) of Tripura, India. Journal of Entomology and Zoology Studies, 6(4): 470-474.

Kamruzzaman, A.A.; Mahamud, M.A.A. and Mansur, M.A. (2018). Proximate composition of Oreochromis niloticus, Heteropneustes fossilis and Pangasius sutchi collected from pond and open water. International Journal of Natural and Social Sciences, 5(2): 84-88.

Mazumder, M.S.A.; Rahman, M.M.; Ahmed, A.T.A.; Begum, M. and Hossain, M.A. (2008). Proximate composition of some small indigenous fish species (SIS) in Bangladesh. International Journal of sustainable crop production, 3(4): 18-23.

Mohanty, B.P.; Behera, B.K. and Sharma, A.P. (2011). Nutritional significance of small indigenous fishes in human health. Central Inland Fisheries Research Institute: Indian Council of Agricultural Research, Bulletin No. 162.

Nowsad, AKM. (2007). Participatory Training of Trainers, Bangladesh Fisheries Research Forum, Mymensingh, Bangladesh.

Paul, B.N.; Chanda, S.; Bhowmick, S.; Sridhar, N.; Saha, G.S. and Giri, S.S. (2017). Nutrient profile of Indian climbing perch, Anabas testudineus. SAARC Journal of Agriculture, 15(1): 99-109.

Paul, B. N.; Chanda, S.; Sridhar, N.; Saha, G.S. and Giri, S.S. (2015). Proximate and Mineral Composition of Magur (Clarias batrachus) and Singhi (Heteropneustes fossilis). Indian Journal of Animal Nutrition, 32 (4): 453-456.

Siddique, M.N.; Hasan, M.J.; Reza, M.Z.; Islam, M.R.; Boduruzaman, M.; Forhadur, M. and Reza, S. (2011). Effect of freezing time on nutritional value of Jatpunti (Puntius sophore), Sarpunti (P. sarana) and Thaisarpunti (P. gonionotus). Bangladesh Research Publications Journal, 5(4): 387-392.

Stansby, M. E. (1962). Proximate composition of fish. In: Heen, E. et al. Fish Nutrition: 55-60.

Thilsted, S.H.; Roos, N. and Hassan, N. (1997). The role of small indigenous fish species in food and nutrition security in Bangladesh. Naga, the ICLARM quarterly, 20(3-4): 82-84.

Wahab, M.A.; Thilsted, S.H. and Hoq, M.E. (eds). (2003). Small Indigenous Species of Fish in Bangladesh. Proceedings of BAUENRECA/DANIDA Workshop on Potentials of small indigenous species of fish (SIS) in aquaculture and rice-field stocking for improved food and nutrition security in Bangladesh, 30-31 October 2002, Bangladesh Agricultural University, Mymensingh, Bangladesh and ENRECA / DANIDA, 166.

Zaman, M.; Naser, M.N.; Abdullah, A.T.M. and Khan, N. (2014). Nutrient contents of some popular freshwater and marine fish species of Bangladesh. Bangladesh Journal of Zoology, 42(2): 251-259. 